\title{
XLVI. On drying articles of manufacture, and heating buildings, by steam
}

\section{R. Buchannan Esq.}

To cite this article: R. Buchannan Esq. (1808) XLVI. On drying articles of manufacture, and heating buildings, by steam , Philosophical Magazine Series 1, 30:119, 225-226, DOI: 10.1080/14786440808563808

To link to this article: http://dx.doi.org/10.1080/14786440808563808

册 Published online: 18 May 2009.

Submit your article to this journal $₫$

Џ Article views: 2

Q View related articles $\sqsubset$ 
yeometry of crystals, we shall find the most convincing proofs that the zoysite should be joined to the epidote, like the mineral of Norway, which a deceitful indication of its characters had made to be placed in a particular species under the names of arendalite and akanticone.

XLVI. On drying Articles of Manufacture, and heating Buildings, by Steam. By R. Buchannan, Esq., Civil Engineer, Glasgow.

TrR,
$\mathbf{M}_{\text {ANY }}$ additional facts with regard to heating by steam have lately been ascertained in this neighbourhood, and its application to various processes in manufactures continues to increase. Mr. Richard Gillespie is highly pleased with its effects upon copper-plate callico-printing at his works, as also for heating his calenders. For this last purpose, and to warm his warehouse and counting-house, the steam is conveyed to a distance of above ninety-three yards.

Steam was, I believe, tried many years ago at Leods, for drying goods, as a substitute for stoves; but for some reason, of which I am ignorant, was abandoned. Mr. Lounds, at Paisley, however, has for a considerable time used it with great success in drying fine muslins. Messrs. Leys, Mason and Co. now also use it at their bleaching works, at Aberdeen.

Some kinds of muslins have for several years been dried by being rolled round cylinders of tin plate filled with steam, but I do not here allude to that mode.

For drying of dyed yarn and pullicates, (a kind of coloured chequed cotton handkerchiefs,) a higher temperature than for fine muslin is required. I am glad, however, to have it in my power to say, that Messrs. Muir, Brown, and Co., at their dveing and bleaching works here, have found steam to answer those purposes much better than the usual mode by stoves. Mr. Muir informs me, that, although they formerly gave out their pullicates to be bleached

Vol. 30. No. 119. April 1808. 


\section{On the Uses of Leaves and Prunings of Vines.}

to some of the local bleachers in this part of the country, the never had their colours in the same perfection which they now have, and which they attribute entirely to the superior effect of the steam.

It occurs to me, that steam might be applied for warming buildings in I.ondon, in many instances, with great advantage. For instance, the bed-rooms of large inns and hotels ; as also large warehouses or shops, where a number of neighbouring buildings might be warmed from one boiler, which would save much in attendance and fuel, as well as in the cost of the apparatus. It is also well adapted to the purpose of warming cburches, hospitals, and other large public buildings. I am, sir, your most obedient servant,

Glasgow, April 2, 1808.

Robertson Buchannan.

XLVII. On the oconomical Uses to which the Leaves and Prunings of Vines may be applied in this Country.

SIR,

To Mr. Tilloch.

$F_{\text {rom experiments which } I \text { have made, I find that, on }}$ being dried, which should be done in the shade, and infused in a tea-pot, the leaves of the vine make an excellent substitute for tea. I have also found that, on being cut small, bruised, and put into a vat, or mashing-tub, and boiling water poured on them, in the same way as is done with malt, the prunings of the vine produce a liquor of a fine vinous quality; which, on being fermented, makes a very fine beverage, either strong or weak, as you please; and, on being distilled, produces an excellent spirit of the nature of brandy.

In the course of my experiments I found that the fermented liquor from the prunings, particularly the tendrils, when allowed to pass the vinous and to run into the acetous fermentation, makes uncommonly fine vinegar. If not intended to be distilled soon after they are lopped off, or if it should not be convenient to do so at the time, they should 